\title{
Morphology and isozyme variation among madeira vine (Anredera cordifolia) accessions from southeastern part of Central Java, Indonesia
}

\author{
RESTYKANIA, SURATMAN, ARI PITOYO, SURANTO \\ Department of Biology, Faculty of Mathematics and Natural Sciences, Universitas Sebelas Maret. Jl. Ir. Sutami 36A Surakarta 57 126, Central Java, \\ Indonesia. Tel./fax.: +62-271-663375, `email: suratman@staff.uns.ac.id
}

Manuscript received: 2 September 2019. Revision accepted: 24 September 2019.

\begin{abstract}
Restykania, Suratman, Pitoyo A, Suranto. 2019. Morphology and isozyme variation among madeira vine (Anredera cordifolia) accessions from southeastern part of Central Java, Indonesia. Biodiversitas 20: 3024-3032. The genetic diversity among madeira vine accessions from southeastern part of Central Java has not been investigated in detail. Information on genetic diversity and relationship among accessions of this plant will provide important input into determining resourceful management strategies and guiding the improvement of plants through plant breeding programs. The objective of this study was to evaluate variation of morphology and isozyme among madeira vine (Anredera cordifolia (Ten.) Steenis) accessions from southeastern part of Central Java. A total of 13 madeira vine accessions were used for morphological observations and isozyme analysis. Morphological diversity was characterized based on measurements and observations of vegetative structures such as stems, leaves, and aerial tubers. Identification of biochemical markers was done using peroxidase and esterase isozyme systems. A relationship dendrogram among accessions was constructed based on the genetic similarity matrix by applying a cluster analysis. The analysis of quantitative and qualitative morphological characters revealed that the majority of the tested traits showed variation, indicating that there was variability among the tested madeira vine accessions. Polymorphism was observed using isozyme of peroxidase (i.e. two banding patterns) and esterase (i.e. five banding patterns). Based on the dendrogram at a level of $63 \%$ similarity, it showed distinct separation of 13 madeira vine accessions into two major clusters. Cluster I consisted of nine accessions and the closest relationship was shown between KLT 3 and KLT 1 accessions that had $94 \%$ of similarity coefficient. The remaining four accessions were clustered separately as Cluster II with similarity coefficient of 73 $\%$. Therefore, genetic characterization based on morphological and isozyme markers obtained in this study is valuable to understand genetic variability and relationship among madeira vine accessions in southeastern part of Central Java.
\end{abstract}

Keywords: Anredera cordifolia, isozyme, madeira vine, morphology, southeastern part of Central Java

\section{INTRODUCTION}

Anredera cordifolia (Ten.) Steenis (syn. Bossingaultia cordifolia Tenore, Boussingaultia gracilis Miers) is a climber plant native to the central and southern parts of South America, from Paraguay to Southern Brazil, Uruguay and Northern Argentina (Eriksson 2007; VivianSmith et al. 2007; Boyne et al. 2013). It belongs to the family Basellaceae, a family with 19 accepted species of four genera (The Plant List 2013).

It is known as "madeira vine" as the preferred common name. The other local names for this plant include "binahong" (Indonesian), "Dhen San Chi" (Chinese), and "parra de Madeira" (Spanish) (Sukandar et al. 2013; GISD 2015). Madeira vine is commonly grown as an ornamental species, but it has been naturalized and now regarded as an environmental weed in some region such as Australia, New Zealand, Hawaii, South Africa, and Pacific Islands. Madeira vine has become a major problem in some areas due to its invasiveness (PIER 2000; Starr et al. 2003; Vivian-Smith et al. 2007). Many studies were performed to determine the best way to control its spread (Webb and Harrington 2005).

Apart from the risk of causing problem as an environmental weed, madeira vine is also credited as having beneficial values. Martinevski et al. (2013) reported the nutritional value of madeira vine, where it is considered an unusual vegetable, with high nutritional value and known as spinach gaucho, leaf-fat and leaf-santa in Brazil (Kinupp et al. 2004). It can be used as a leafy vegetable because it has shown neither toxicity nor mutagenic effects (Yen et al. 2001; Mao-Te et al. 2007).

Madeira vine is also known as a medicinal plant. It is used traditionally to treat various diseases such as skin disease, hypertension, inflammation and gout (Sukandar et al. 2013). Some studies have reported the antimicrobial activity of madeira vine extract on Staphylococcus aureus, Enterococcus faecalis, Escherichia coli, Pseudomonas aeruginosa, Vibrio harveyi and Mycobacterium tuberculosis (Amertha et al. 2012; Darsana et al. 2012; Kartika et al. 2016; Pitaloka et al. 2018). Ethanolic extract of madeira vine stem showed antifungal activity against Candida albicans (Kumalasari and Sulistyani 2011). The ethanolic extract of madeira vine leaves also improves wound healing activity (Miladiyah and Prabowo 2012). The other multiple uses of madeira vine as medicinal plant, as reported by many researchers include as hepatoprotection (Orbayinah and Kartyanto 2008), antiinflammatory (Sumartiningsih 2011), anti-obesity (Wang et al. 2011), antioxidant (Djamil et al. 2012), anti-diabetic (Sukandar et al. 2011), increasing breast milk production (Panyaphua et al. 2011), and improving the failure of 
kidney (Sukandar et al. 2013). Madeira vine leaves contain triterpenoid, steroid saponins, alkaloids, flavonoids, polyphenols, quinones, monoterpenoids, sesquiterpenoids, coumarins, polysaccharides phytol, essential oil, $\alpha$-pinene and 6,10,14-trimethyl-2-pentadecanone (Zeid et al. 2007; Murni et al. 2011; Djamil et al. 2012; Sukandar et al. 2013; Souza et al. 2014) while their rhizome contains flavanoid, polyphenol, tannin, and steroid (Sukandar et al. 2011).

In order to assess genetic variability of plants, a variety of markers method has been used. Morphological markers have been commonly used as a first step in germplasm characterization. Although morphological characters have been traditionally used to characterize levels and patterns of diversity, it has been found that the genetic information provided by these traits is often limited because it only represents a small portion of plant genome and is influenced by environmental factors (Nongdam and Nirmala 2007; Johnson et al. 2010). Despite this limitation, morphological characterization is still useful for preliminary evaluation because it is fast, simple, and can be used as a general approach for assessing genetic diversity among morphologically distinguishable accessions (Beyene et al. 2005; Said and Ehsan 2010; Suratman et al. 2016).

In recent years, limitations of morphological markers have been overcome by biochemical and molecular markers. Isozymes, as the classical biochemical marker, are accepted as the best descriptors of genetic variability since they exhibit very low levels of environmental interactions (Geethalakshmi et al. 2005). Analysis of isozyme has been used extensively to provide quantitative estimates of the extent of genetic variation within the species (Ivy et al. 2010). Isozymes have played a key role in identifying genotypes and understanding relationships among closely related individuals (Kumar et al. 2013). Isozymes are relatively cheaper and simple to use in variety of applications in plant research. Isozymes have the advantage that material is processed by an efficient and inexpensive technique without requiring prior knowledge of the genome (Johnson et al. 2010).

The genetic diversity among madeira vine accessions from southeastern part of Java has not been investigated in detail. Information on genetic diversity and relationship among accessions of this plant will provide important input into determining resourceful management strategies and guiding the improvement of plants through plant breeding programs, especially in facilitating breeding material selection. The objective of this study was to evaluate morphology and isozyme variation among madeira vine accessions from southeastern part of Central Java (Indonesia). The assessment of genetic variation among madeira vine accessions from Java-based on morphological and isozyme markers was the first study reported from this region.

\section{MATERIALS AND METHODS}

\section{Plant materials}

A total of 13 madeira vine accessions were used for morphological observations and isozyme analysis. These accessions were collected from a wide range of sites in the form of living plant collection (Figure 1, Table 1). All of them were maintained in greenhouse for 10 weeks. The plants were grown under controlled environmental conditions with temperature regime of $27^{\circ} / 21^{\circ} \mathrm{C}$ day/night, relative air humidity of $85 \%$, at a photon flux density of about 7.600 lux and at $126 \mathrm{~m}$ asl altitude. The young leaves of each accession were then used for isozymes extraction.

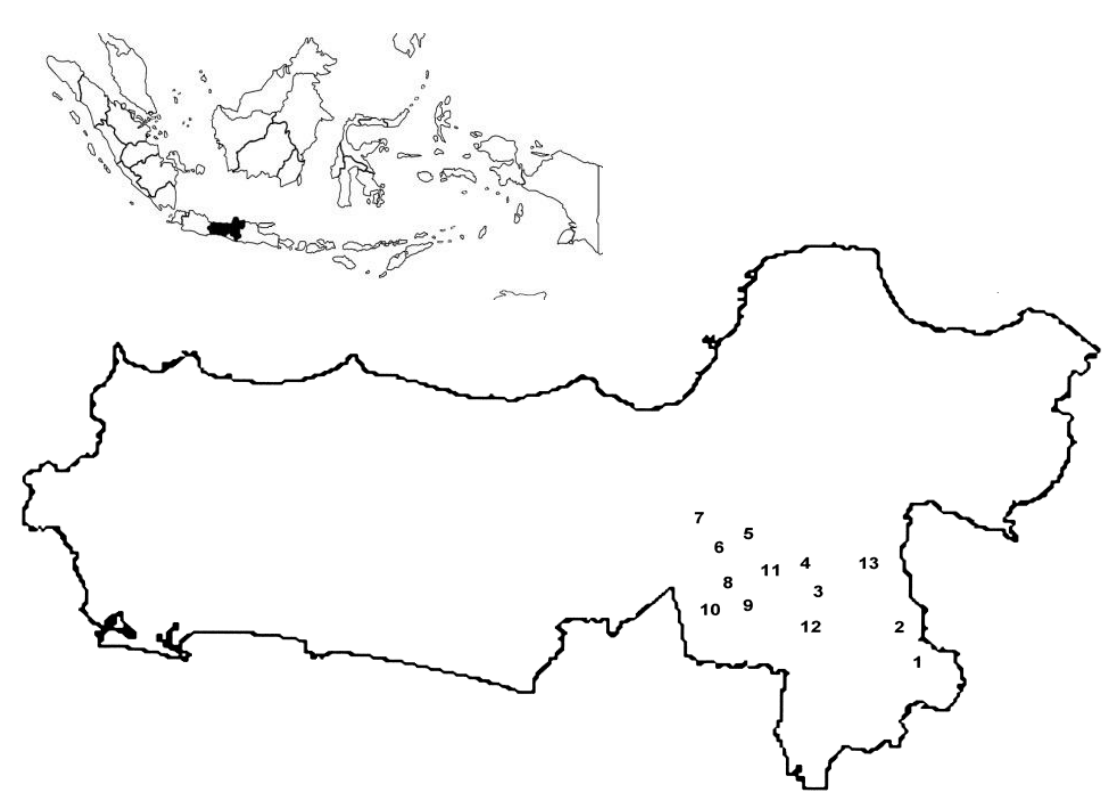

$\mathbf{A}$

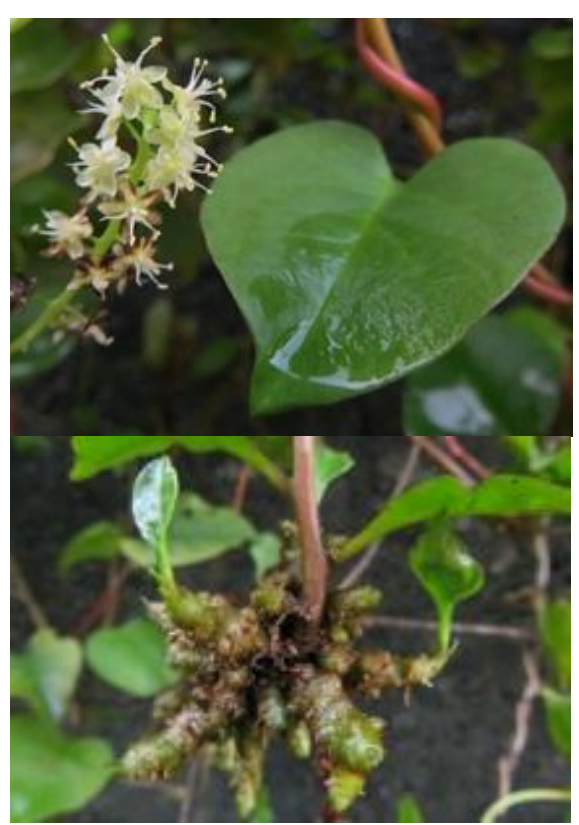

B

Figure 1. A. Map of the collection areas of madeira vine (A. cordifolia) accessions in southeastern part of Central Java. The number (1 to 13) indicated location of each collected accession as presented in Table 1. B. Habit of madeira vine (Typical Gardener 2014). 
Table 1. Biophysical conditions of the sites where madeira vine (A. cordifolia) accessions were originated from southeastern part of Central Java, Indonesia

\begin{tabular}{lllccccc}
\hline \multirow{2}{*}{ No. } & \multirow{2}{*}{ Accessions } & \multicolumn{1}{c}{ Collection site } & $\begin{array}{c}\text { Altitude } \\
(\mathbf{m} \text { a.s.l.) }\end{array}$ & $\begin{array}{c}\text { Air temperature } \\
\left(\mathbf{o}^{\mathbf{C}}\right)\end{array}$ & $\begin{array}{c}\text { Light intensity } \\
(\mathbf{l u x})\end{array}$ & $\begin{array}{c}\text { Air humidity } \\
(\boldsymbol{\%})\end{array}$ & $\begin{array}{c}\text { Soil humidity } \\
(\%)\end{array}$ \\
\hline 1 & WNG 1 & Ploso, Wonogiri & 472 & 28 & 2.400 & 83 & 60 \\
2 & WNG 2 & Bukukerto, Wonogiri & 533 & 25 & 2.600 & 95 & 85 \\
3 & KRY 1 & Jumantono, Karanganyar & 273 & 33 & 5.200 & 72 & 20 \\
4 & KRY 2 & Karangsari, Karanganyar & 615 & 33 & 10.500 & 65 & 90 \\
5 & BYL 1 & Ngemplak, Boyolali & 141 & 34 & 7.600 & 60 & 20 \\
6 & BYL 2 & Teras, Boyolali & 297 & 31 & 3.100 & 78 & 60 \\
7 & BYL 3 & Cepogo, Boyolali & 1.000 & 32 & 1.000 & 62 & 40 \\
8 & KLT 1 & Krecek, Klaten & 246 & 31 & 8.100 & 79 & 20 \\
9 & KLT 2 & Maduan, Klaten & 377 & 28 & 2.000 & 84 & 80 \\
10 & KLT 3 & Mblorong, Klaten & 756 & 34 & 12.800 & 75 & 20 \\
11 & SKA & Laweyan, Surakarta & 122 & 30 & 6.100 & 72 & 50 \\
12 & SKH & Bekonang, Sukoharjo & 144 & 37 & 8.200 & 67 & 20 \\
13 & SRG & Masaran, Sragen & 99 & 30 & 700 & 79 & 100 \\
\hline
\end{tabular}

\section{Morphological characterization}

Morphological diversity was characterized based on measurements and observations of vegetative structures of the madeira vine plant such as stems, leaves, and aerial tubers. Measurements of quantitative morphological characters included stem length, stem diameter, leaf length, leaf width, ratio of length: width leaf, petiole length, petiole width, aerial tuber length, and aerial tuber diameter. All measurements were averaged and averages for each plant were used in subsequent analyses (Suratman et al. 2016; Pitoyo et al. 2018). The observation of qualitative morphological characters included color of leaf upper surface, color of young stem, color of old stem, and surface of old stem.

\section{Isozyme analysis}

Isozymes were analyzed from young leaves taken from mature plants. Enzymes were extracted, electrophoresed, stained and characterized as described by Suranto (2001), Setyawan et al. (2014), Suratman et al. (2016) and Pitoyo et al. (2018). A total of $0.6 \mathrm{~g}$ young leaves of maderira vein were ground in mortar using $1800 \mu \mathrm{l}$ of extraction buffer and then transferred to a $1.5 \mathrm{ml}$ microtube. The extraction buffer consisted of $0.018 \mathrm{~g}$ cysteine, $0.021 \mathrm{~g}$ ascorbic acid and $5 \mathrm{~g}$ sucrose distilled in $20 \mathrm{ml}$ borax buffer at $\mathrm{pH} 8.4$. Samples were then centrifuged at $12000 \mathrm{rpm}$ for 5 minutes, and supernatant was transferred to new microtube. Two enzyme systems (esterase and peroxidase) were analyzed using acrylamide gel electrophoresis. About $200 \mu \mathrm{l}$ of supernatant was taken and $5 \mu \mathrm{l}$ of bromophenol blue (tracking dye) was added to each sample. About 10-24 ul of prepared samples (10-15 ul for peroxidase and 15-24 ul for esterase) was taken and loaded into each well of acrylamide gel. Loaded samples were electrophoresed at a constant current of $5 \mathrm{~mA}$ for peroxidase and $7 \mathrm{~mA}$ for esterase at room temperature for about 60 minutes. After electrophoresis, the gels were stained with a staining solution specific for the appropriate enzyme systems. Gels were immersed in the staining solutions under dark condition until the clear bands appeared. After staining was complete, gels were rinsed first with distilled water, then with $10 \%$ acetic acid solution. The gel was transferred to a fixative solution that contained 50\% methanol and then placed in zip-lock bags, and stored at $4^{0} \mathrm{C}$ in refrigerator until it could be analyzed and photographed (Fernandez et al. 1996; Johnson et al. 2010; Tiwari and Bakshi 2015).

\section{Data analysis}

All quantitative morphological characters data were analyzed using analysis of variance (Suratman et al. 2016; Pitoyo et al. 2018) in order to test the significance of variation (i.e. difference) among madeira vine accessions. The observed qualitative morphological characters among all tested madeira vine accessions were then descriptively analyzed. The data from zymograms were entered as a matrix of presence/absence of bands for each enzyme system. A relationship dendrogram among madeira vine accessions based on morphological and isozyme markers was constructed based on the genetic similarity matrix by applying SAHN procedure, using the Unweighted Pair Group Method with Arithmetic Averages (UPGMA) cluster analysis using a computer program, NTSYS ver. 2.00 (Rohlf 1998; Suratman et al. 2016; Pitoyo et al. 2018).

\section{RESULTS AND DISCUSSION}

\section{Morphological analysis}

A total of thirteen morphological characters consisted of nine quantitative and four qualitative characters were selected for morphological study among all tested madeira vine accessions. The selected character such as length: width leaf was scaled using ratio to eliminate size differences that might be caused by environmental factors.

The analysis of variance for quantitative morphological characters revealed that there was no significant difference $(p<0.05)$ among madeira vine accessions for the majority of the tested quantitative morphological traits except in case of variation of stem length. Stem diameter, leaf length, leaf wide, ratio of length: width leaf, petiole length, petiole width, aerial tuber length, aerial tuber diameter also showed a narrower range of phenotypic variation (Table 2). 
The stem length varied significantly among 13 tested accessions and displayed a range from $28 \mathrm{~cm}$ (BYL 2) to $154 \mathrm{~cm}$ (WNG 1) with an average of $141 \mathrm{~cm}$. Stem diameter showed narrower variation and ranged from 0.2 cm (WNG 2, KRY 1, KLT 3, SRG) to $0.4 \mathrm{~cm}$ (SKH) with an average of $0.28 \mathrm{~cm}$. Leaf length exhibited narrower differences among accessions and ranged from $3.3 \mathrm{~cm}$ (BYL 2) to $5.7 \mathrm{~cm}$ (WNG 1) with an average of $4.1 \mathrm{~cm}$. Leaf width displayed narrower differences among accessions and varied from $2.3 \mathrm{~cm}$ (BYL 2) to $4.8 \mathrm{~cm}$ (WNG 1) with an average of $3.38 \mathrm{~cm}$. Leaf length: width ratio showed narrower differences among accessions and varied from 1 (KRY 2, BYL 1, KLT 3, SKA, SKH) to 1.4 (KRY 1, BYL 2, KLT 1, SRG) with an average of 1.2. Petiole length did not vary significantly among accessions and displayed a range from $0.6 \mathrm{~cm}$ (BYL 3, KLT 1) to 1.3 $\mathrm{cm}$ (WNG 1, KLT 1), with an average of $0.84 \mathrm{~cm}$. Petiole width did not differ significantly among tested accessions and ranged from $0.1 \mathrm{~cm}$ (BYL 2, KLT 1, KLT 3, SRG) to $0.3 \mathrm{~cm}$ (WNG 1, WNG 2), with an average of $0.18 \mathrm{~cm}$. Aerial tuber length showed narrower differences among accessions and varied from $0.2 \mathrm{~cm}$ (SKA) to $1.8 \mathrm{~cm}$ (WNG
2) with an average of $0.86 \mathrm{~cm}$. Aerial tuber diameter values also showed narrower variation and ranged from $0.1 \mathrm{~cm}$ (BYL 1, KLT 1, SKA) to $0.4 \mathrm{~cm}$ (WNG 2, BYL 3) with an average of $0.23 \mathrm{~cm}$.

Based on Table 3, the observation of qualitative morphological characters showed that color of leaf upper surface in some accessions (WNG 1, WNG 2, KRY 2, BYL 3, KLT 2, SKA) reported as dark green and the remaining accessions (KRY 1, BYL 1, BYL 2, KLT 1, KLT 3, SKH, $\mathrm{SRG}$ ) were pale green. Colour of young stem was green in some accessions (WNG 1, KRY 1, BYL 1, BYL 2, BYL 3, KLT 1, KLT 3) and reddish-green in other accessions (WNG 2, KRY 2, KLT 2, SKA, SKH, SRG). Colour of old stem was reported as brown in some accessions (WNG 1, BYL 1, KLT 1, SKA), while reddish-green in other accessions (WNG 2, KLT2) and brownish-green in the remaining accessions (KRY 1, KRY 2, BYL 2, BYL 3, KLT 3, SKH, SRG). The surface of old stem was glabrous in some accessions (WNG 2, KRY 2, BYL 2, BYL 3, KLT 1, KLT 2, KLT 3, SKH, SRG) and nodular in other accessions (WNG 1, KRY 1, BYL 1, SKA).

Table 2. Quantitative morphological character variation among madeira vine accessions from southeastern part of Central Java, Indonesia

\begin{tabular}{|c|c|c|c|c|c|c|c|c|c|c|}
\hline No. & Accessions & StL & StD & LfL & LfW & LfR & PtL & PtW & ToL & ToD \\
\hline 1 & WNG 1 & $154 c$ & $0.3 \mathrm{ab}$ & $5.7 b$ & $4.8 b$ & $1.2 \mathrm{ab}$ & $1.3 \mathrm{~b}$ & $0.3 \mathrm{a}$ & $1.5 \mathrm{~b}$ & $0.3 \mathrm{ab}$ \\
\hline 2 & WNG 2 & $73 a b$ & $0.2 \mathrm{a}$ & $5.3 \mathrm{~b}$ & $4.3 \mathrm{~b}$ & $1.2 \mathrm{ab}$ & $1.1 \mathrm{ab}$ & $0.3 \mathrm{a}$ & $1.8 \mathrm{~b}$ & $0.4 \mathrm{~b}$ \\
\hline 3 & KRY 1 & $69 a$ & $0.2 \mathrm{a}$ & $4.3 \mathrm{ab}$ & $3.0 \mathrm{a}$ & $1.4 \mathrm{~b}$ & $0.8 \mathrm{a}$ & $0.2 \mathrm{a}$ & $1.1 \mathrm{ab}$ & $0.3 \mathrm{ab}$ \\
\hline 4 & KRY 2 & $133 b c$ & $0.3 \mathrm{ab}$ & $3.5 \mathrm{a}$ & $3.4 \mathrm{ab}$ & $1.0 \mathrm{a}$ & $1.0 \mathrm{ab}$ & $0.2 \mathrm{a}$ & $0.8 \mathrm{a}$ & $0.2 \mathrm{a}$ \\
\hline 5 & BYL 1 & $138 \mathrm{bc}$ & $0.3 \mathrm{ab}$ & $4.5 \mathrm{ab}$ & $4.4 \mathrm{~b}$ & $1.0 \mathrm{a}$ & $1.3 b$ & $0.2 \mathrm{a}$ & $1.2 \mathrm{ab}$ & $0.1 \mathrm{a}$ \\
\hline 6 & BYL 2 & $28 \mathrm{a}$ & $0.3 \mathrm{ab}$ & $3.3 \mathrm{a}$ & $2.3 \mathrm{a}$ & $1.4 \mathrm{~b}$ & $0.7 \mathrm{a}$ & $0.1 \mathrm{a}$ & $0.5 \mathrm{a}$ & $0.2 \mathrm{a}$ \\
\hline 7 & BYL 3 & $35 \mathrm{a}$ & $0.3 \mathrm{ab}$ & $3.7 \mathrm{a}$ & $2.8 \mathrm{a}$ & $1.3 \mathrm{ab}$ & $0.6 \mathrm{a}$ & $0.2 \mathrm{a}$ & $1.4 \mathrm{ab}$ & $0.4 \mathrm{~b}$ \\
\hline 8 & KLT 1 & $39 a$ & $0.3 \mathrm{ab}$ & $3.6 \mathrm{a}$ & $2.6 \mathrm{a}$ & $1.4 \mathrm{~b}$ & $0.6 \mathrm{a}$ & $0.1 \mathrm{a}$ & $0.3 \mathrm{a}$ & $0.1 \mathrm{a}$ \\
\hline 9 & KLT 2 & $35 a$ & $0.3 \mathrm{ab}$ & $3.6 \mathrm{a}$ & $2.7 \mathrm{a}$ & $1.3 \mathrm{ab}$ & $0.8 \mathrm{a}$ & $0.2 \mathrm{a}$ & $0.6 \mathrm{a}$ & $0.2 \mathrm{a}$ \\
\hline 10 & KLT 3 & $52 \mathrm{a}$ & $0.2 \mathrm{a}$ & $4.1 \mathrm{ab}$ & $3.6 \mathrm{ab}$ & $1.0 \mathrm{a}$ & $0.8 \mathrm{a}$ & $0.1 \mathrm{a}$ & $0.4 \mathrm{a}$ & $0.2 \mathrm{a}$ \\
\hline 11 & SKA & $41 \mathrm{a}$ & $0.3 \mathrm{ab}$ & $4.0 \mathrm{ab}$ & $3.6 \mathrm{ab}$ & $1.0 \mathrm{a}$ & $0.8 \mathrm{a}$ & $0.2 \mathrm{a}$ & $0.2 \mathrm{a}$ & $0.1 \mathrm{a}$ \\
\hline 12 & SKH & $150 \mathrm{c}$ & $0.4 \mathrm{~b}$ & $4.2 \mathrm{ab}$ & $4.0 \mathrm{~b}$ & $1.0 \mathrm{a}$ & $1.0 \mathrm{ab}$ & $0.2 \mathrm{a}$ & $0.8 \mathrm{a}$ & $0.2 \mathrm{a}$ \\
\hline \multirow[t]{2}{*}{13} & SRG & $128 b c$ & $0.2 \mathrm{a}$ & $3.5 \mathrm{a}$ & $2.5 \mathrm{a}$ & $1.4 \mathrm{~b}$ & $1.0 \mathrm{ab}$ & $0.1 \mathrm{a}$ & $0.6 \mathrm{a}$ & $0.3 \mathrm{ab}$ \\
\hline & Average & 141 & 0.28 & 4.1 & 3.38 & 1.20 & 0.84 & 0.18 & 0.86 & 0.23 \\
\hline
\end{tabular}

Note: * StL = stem length $(\mathrm{cm}) ; \mathrm{StD}=$ stem diameter $(\mathrm{cm}) ; \mathrm{LfL}=$ leaf length $(\mathrm{cm}) ; \mathrm{LfW}=$ leaf width $(\mathrm{cm}) ; \mathrm{LfR}=$ ratio of length: width leaf; PtL = petiole length $(\mathrm{cm}) ; \mathrm{PtW}=$ petiole width $(\mathrm{cm}) ; \mathrm{ToL}=$ aerial tuber length $(\mathrm{cm})$; ToD = aerial tuber diameter $(\mathrm{cm})$. ** Values followed by the different lower-case letter in the same column are significantly different (Duncan multiple range test, $p<0.05$

Table 3. Qualitative morphological character variation among madeira vine accessions from southeastern part of Central Java, Indonesia

\begin{tabular}{llllll}
\hline No. & Accessions & $\begin{array}{l}\text { Color of leaf upper } \\
\text { surface }\end{array}$ & Color of young stem & $\begin{array}{l}\text { Color of } \\
\text { old stem }\end{array}$ & $\begin{array}{l}\text { Surface of } \\
\text { old stem }\end{array}$ \\
\hline 1 & WNG 1 & Dark green & Green & Brown & Nodular \\
2 & WNG 2 & Dark green & Reddish green & Reddish green & Glabrous \\
3 & KRY 1 & Pale green & Green & Brownish green & Nodular \\
4 & KRY 2 & Dark green & Reddish green & Brownish green & Glabrous \\
5 & BYL 1 & Pale green & Green & Brown & Godular \\
6 & BYL 2 & Pale green & Green & Brownish green & Glabrous \\
7 & BYL 3 & Dark green & Green & Brownish green & Glabrous \\
8 & KLT 1 & Pale green & Green & Brown & Glabrous \\
9 & KLT 2 & Dark green & Reddish green & Reddish green & Glabrous \\
10 & KLT 3 & Pale green & Green & Brownish green & Godular \\
11 & SKA & Dark green & Reddish green & Brown & Glabrous \\
12 & SKH & Pale green & Reddish green & Brownish green & Brownish green \\
13 & SRG & Pale green & Reddish green & Brous & \\
\hline
\end{tabular}




\section{Isozyme analysis}

Polymorphism was observed in madeira vine accessions from Central Java using isozymes of esterase and peroxidase marker. Esterase and peroxidase have been widely utilized to assess the genetic similarity and to reveal the variation of organisms at the various taxonomic levels (Pitoyo et al. 2018). The two enzymatic systems showed a total of 7 banding patterns, distributed in the whole set of samples as peroxidase with 2 banding patterns and esterase with 5 banding patterns.

Peroxidase analysis showed two patterns of zymogram (banding pattern $\mathrm{A}$ and $\mathrm{B}$ ) which distributed in different $\mathrm{Rf}$ value varying from 0.02 to 0.34 . Banding pattern $A$ occurred in the majority of accessions and distributed in 11 tested madeira vine accessions (SRG, SKA, SKH, WNG 2, WNG 1, KRY 1, KRY 2, KLT 2, BYL 1, BYL 2, BYL 3). Banding pattern A consisted of three bands which located at Rf 0.02 , Rf 0.08 and Rf 0.34. Banding pattern B only distributed in two accessions (KLT 1 and KLT 2) and consisted of three bands which located at Rf 0.02, Rf 0.12 and Rf 0.34 (Figure 2).

Seven bands of esterase at different $\mathrm{Rf}$ values varying from 0.02 to 0.28 were observed, which allowed to distinguish five patterns of zymograms (banding pattern A, B, C, D, and E) (Figure 3). Banding pattern A only distributed in SRG accession and consisted of four bands which located at Rf 0.02 , Rf 0.06, Rf 0.18 and Rf 0.28. Banding pattern $\mathrm{B}$ distributed in three accessions (SKA,
SKH, WNG 2) and consisted of four bands which located at Rf 0.02 , Rf 0.06, Rf 0.14 and Rf 0.28. Banding pattern $\mathrm{C}$ distributed in five accessions (WNG 1, BYL 2, BYL 3, KRY 1, KRY 2) and consisted of four bands which located at $\mathrm{Rf} 0.04, \mathrm{Rf} 0.06, \mathrm{Rf} 0.14$ and $\mathrm{Rf} 0.28$. Banding pattern D distributed in two accessions (KLT 1, KLT 3) and consisted of four bands which located at Rf 0.04, Rf 0.08, Rf 0.14 and $\mathrm{Rf}$ 0.28. Banding pattern $\mathrm{E}$ distributed in two accessions (KLT 2, BYL 1) and consisted of four bands which located at Rf 0.04, Rf 0.06, Rf 0.18 and Rf 0.28.

\section{Similarity among madeira vine accessions}

Based on the dendrogram at a level of $63 \%$ similarity, it showed distinct separation of 13 madeira vine accessions from southeastern part of Central Java into two major clusters (Figure 4). Cluster I comprised most of tested accessions originated from all Klaten accessions (KLT 1, KLT 2, and KLT 3), all Boyolali accessions (BYL 1, BYL 2, and BYL 3), Wonogiri accession (WNG 1), Karanganyar accession (KRY 1) and Surakarta accessions (SKA). The closest relationship was showed between KLT 3 and KLT 1 accessions that had $94 \%$ of similarity coefficient. The second cluster was formed by the remaining four accessions from Karanganyar accession (KRY 2), Wonogiri accession (WNG 2), Sukoharjo accession (SKH), and Sragen accession (SRG) with similarity coefficient of $73 \%$ and considered to be genetically unique.

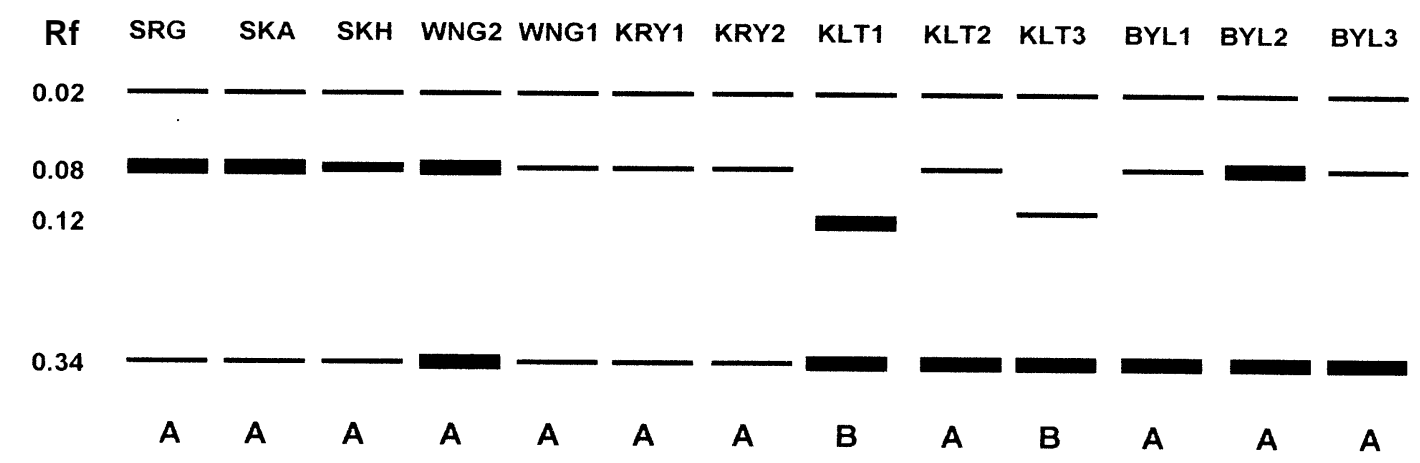

Figure 2. Peroxidase isozymic banding pattern of 13 madeira vine accessions from southeastern part of Central Java, Indonesia

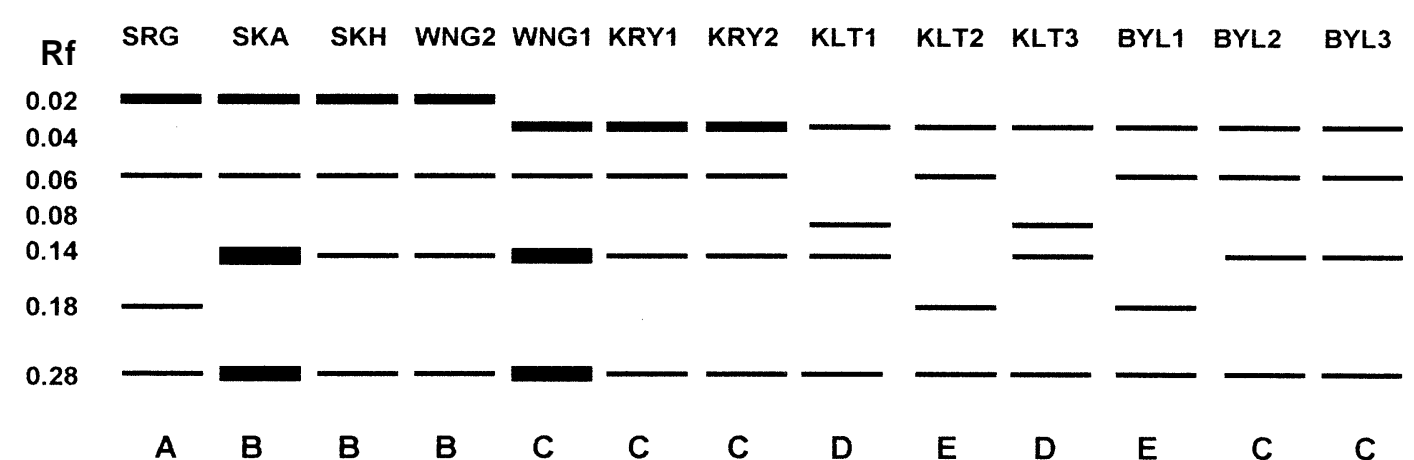

Figure 3. Esteraseisozymic banding pattern of 13 madeira vine accessions from southeastern part of Central Java, Indonesia 


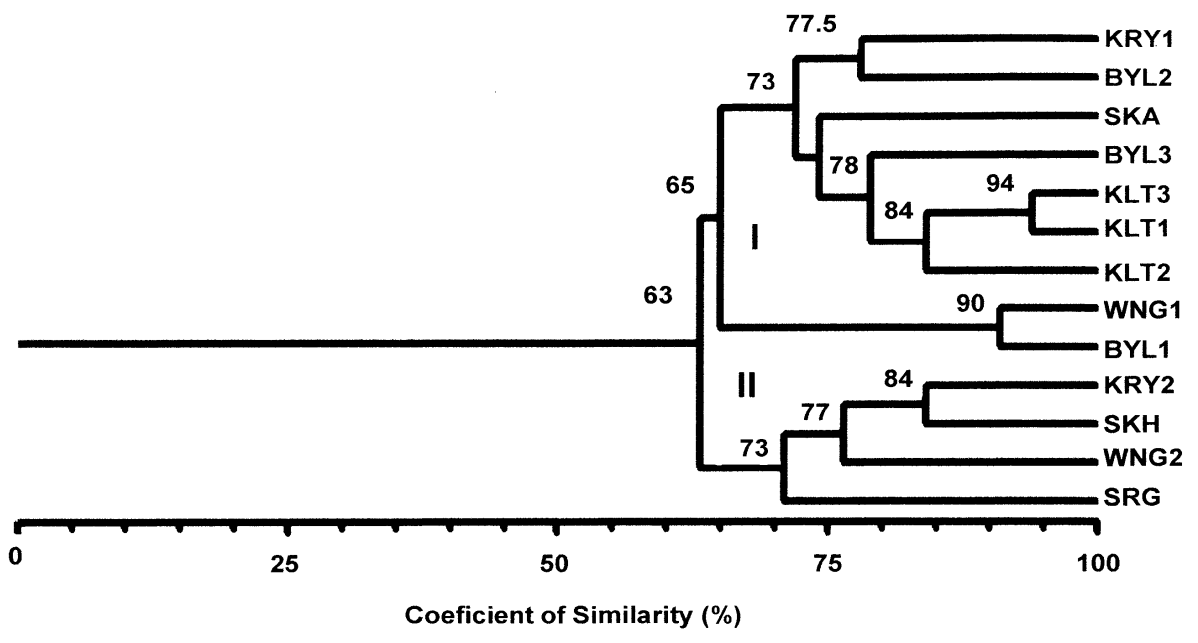

Figure 4. Relationship dendrogram among 13 madeira vine accessions from southeastern part of Central Java, Indonesia using morphological and isozyme markers

\section{Discussion}

Variation is the basic resource to be explored for genetic improvement in any species and hence plays a key role in plant improvement programs (Johnson et al. 2010). Efficient utilization of a germplasm collection requires knowledge of the pattern of genetic variation for traits of economic interest. If the geographic distribution of variation for a trait were unknown, one could base the sampling on patterns of general genetic variation among accessions from different regions (Beer et al. 1993). Morphological markers have been commonly used in germplasm characterization to assess genetic variation among and within species, cultivars, populations or accessions (Acquaah 2012; Padmini et al. 2013).

The quantitative morphological characters analysis of madeira vine accessions in this study revealed the variation among the tested accessions although it appeared to be insignificant for the majority of the tested characters except in case of variation of stem length. The majority of the tested quantitative characters such as stem diameter, leaf length, leaf wide, ratio of length: width leaf, petiole length, petiole width, aerial tuber length, aerial tuber diameter showed a narrower phenotypic variation among accessions. These results further indicated the existence of variability among accessions for these traits although their variation was considered low. The observation of qualitative morphological characters showed that four characters used in this study i.e. color of leaf upper surface, color of young stem, color of old stem, and surface of old stem revealed variation among madeira vine accessions. However, phenotypic variations observation provided a good opportunity for genetic improvement (Sabaghnia et al. 2014).

Thus, utilizing morphological characters has been accepted widely to measure phenotypic diversity in germplasm collection programs. Indeed, although these madeira vine accessions were collected from a wide range of sites and then cultivated under controlled environmental conditions, they retained the characteristic acquired previously. This indication then provided vital information on the morphological diversity (Mbouobda et al. 2007).

In general, this study revealed that the madeira vine accessions showed variation in the majority of tested morphological characters although only morphological character such as stem length had significant difference. Therefore, this indication showed that there is enough scope for selection of desirable characters where variability exists for plant breeding programs (Beyene et al. 2013).

Isozymes are classical biochemical markers for assessing genetic variability in species, among population, and among accessions. Isozymes are especially useful when several taxa, accessions, and individuals are to be compared, as the assumption of homology is more accurate than with some DNA markers (Klaas 1998; Lange and Schifino-Wittmann 2000).

In this study, two enzyme systems (esterases and peroxidases) were used and interpreted to find out the variability among madeira vine accessions from southeastern part of Central Java. The madeira vine accessions can be differentiated effectively by isozyme of esterase and peroxidase because these enzym systems resolved clearly and revealed more detailed variation among all tested accessions. Esterase showed most isozymic banding pattern variations compared than peroxidase in this study. Esterase showed 5 isozymic banding patterns compared peroxidase with 2 isozymic banding patterns.

Peroxidase is an easily detected enzyme because of extraordinary activity on plant tissue (Suratman et al. 2016) but in this study, peroxidase showed narrower variations of isozymic banding pattern among madeira vine accessions. Peroxidase was then considered as the conservative of the enzymatic systems analyzed, with fewer bands and/or banding patterns resulted in this study. 
Esterases are a complex and heterogeneous group of enzymes with multiple substrate specificities. They are generally monomeric or dimeric in plants, with great genetic variability and are one of the enzymatic systems with higher polymorphism in plants (Smila et al. 2007; Rakshit et al. 2011). Variability of esterase isozyme pattern among madeira vine accessions was detected, especially in number, frequency, and thickness of bands. The complexity of the patterns, due to the high number and different type of bands (A, B, C, D, and E) is very informative and useful for characterization, although analysis is complex. Therefore, esterase can be considered as the most suitable of the enzyme systems examined to assess genetic variability in the tested madeira vine accessions. An added advantage of esterase in this kind of analysis is a large number of bands and the excellent stability of the staining technique (Lange and Schifino-Wittmann 2000).

Isozyme analysis provides a very conservative estimate of the extent of genetic variability. A large number of polymorphic zones which were shown in two enzyme systems used in this study were essential as genetic marker and indicated the validity of the isozyme data to study the genetic variability (Kumar et al. 2013). These markers are also generally independent of environmental factors and are more numerous than phenotypic characters providing clear information of underlying variation in the genome of an organism (Amom and Nongdam 2017).

From the present study, it is concluded that in the two tested enzyme systems, esterases and peroxidases, the specific banding pattern can be used for accessions differentiation. Isozyme band patterns, especially when several enzyme systems are employed, are useful and reliable biochemical markers for the taxonomic delimitation and characterization of germplasm. Therefore, difference in the profile of isozymes can be used to reveal genetic diversity among madeira vine accessions. However, an adequate genetic diversity for effective selection in a breeding program is very essential (Geethalakshmi et al. 2005; Pitoyo et al. 2018).

The relationship dendrogram in this study showed that the geographically related accessions were not always clustered in the same group. Probably, there is no correlation between geographic distribution and genetic diversity in this study. Thus, the grouping of madeira vine accessions did not always indicate the similarity of their geographical origins, but maybe due to genetic similarities (Tikader and Kamble 2008). Although the tested madeira vine accessions were collected from different geographical locations and then grown in the same microclimate it was understood that each accession varied with respect to environmental factors and genetic parameters. The genetic variability in madeira vine accessions may be partly explained as a result of abiotic and biotic factors (Suratman et al. 2013). Therefore, germplasm collections from various geographical origins have been important source of novel genetic variability and could be utilized in the crop improvement programs. Further improvement through breeding and selection depends on the novel genetic variability in the elite breeding material (Tang et al. 2014).
Based on the relationship dendrogram, the genetic similarity among madeira vine accessions then could be estimated. Their genetic similarity percentage can be considered as the basic data in the selection of desired accessions for species improvement. Two similar genetically accessions or more but possessing distinct characters can be chosen for this purpose (Lombardi et al. 2014; Suratman et al. 2015). Then, the breeders must have the idea of choosing the accession that most likely possesses the trait of interest (Roy et al. 2013).

Therefore, genetic characterization based on morphological characters and isozyme markers obtained in this study could be valuable for understanding of genetic variability and relationship among the examined madeira vine accessions in southeastern part of Central Java. Biochemical characterization of these accessions through isozyme marker along with morphological characterization will also provide the basic information for utilization of the plants. Information on genetic diversity and relationship among and between individuals, accessions, populations, varieties, and species of plant will also provide important input into determining resourceful management strategies and guiding the improvement of plants through plant breeding programs (Tang et al. 2014; Setyawan et al. 2014).

\section{ACKNOWLEDGEMENTS}

This research was supported partially by a grant from Universitas Sebelas Maret (UNS), Surakarta, Indonesia through Research Group of Plant Biomaterial, Faculty of Mathematics and Natural Sciences (No. Grant: 516/UN27.21/PP/2019).

\section{REFERENCES}

Acquaah G. 2012. Principles of Plant Genetics and Breeding. Second Edition. John Wiley \& Sons Ltd, UK.

Amertha IBPM, Soeliongan S, Kountul C. 2012. In vitro inhibition zone test of binahong (Anredera cordifolia) toward Staphylococcus aureus, Enterococcus faecalis, Escherichia coli, and Pseudomonas aeruginosa. Indones J Biomed Sci 6: 30-34.

Amom T, Nongdam P. 2017. The use of molecular marker methods in plants: a review. Int J Cur Res Rev 9 (17): 1-7.

Beer SC, Goffreda J, Phillips TD, Murphy JP, Sorrells ME. 1993. Assessment of genetic variation in Avena sterilis using morphological traits, isozymes, and RFLPs. Crop Sci 33: 1386-1393.

Beyene P, Botha A, Myburg AA. 2005. A comparative study of molecular and morphological methods of describing genetic relationships in traditional Ethiopian highland maize. Afr J Biotechnol 4 (7): 586-595.

Beyene Y, Mugo S, Semagn K, Asea K, Trevisan K, Tarekegne A, Tefera T, Gethi J, Kiula B, Gakunga J, Karaya H, Chavangi A. 2013. Genetic distance among doubled haploid maize lines and their testcross performance under drought stress and non-stress conditions. Euphytica 192: 379-392.

Boyne RL, Olusegun OO, ScharaschkinT.2013. Variation in leaf structure of the invasive Madeira vine (Anredera cordifolia, Basellaceae) at different light levels. Aust J Bot. DOI: 10.1071/BT13083

Darsana IGO, Besung INK, Mahatmi H. 2012. Potential of binahong (Anredera cordifolia (Ten.) Steenis) leaves in inhibiting the growth of Escherichia coli bacteria by in vitro. Indonesia Medicus Veterinus 1 (3): 337-351. [Indonesian] 
Djamil R, Wahyudi PS, Wahono S, Hanafi M. 2012. Antioxidant activity of flavonoid from Anredera cordifolia (Ten) Steenis leaf. Int Res J Pharm 3: 241-243.

Eriksson R. 2007. A synopsis of Basellaceae. Kew Bulletin 62: 297-320.

Fernandez A, Schutzki RE, Hancock JF.1996. Isozyme and morphological variation in a Cornus florida L. provenance plantation representing geographically diverse populations. J Am Soc Hort Sci 121 (2): 225230.

Geethalakshmi P, Parthasarathy VA, Niral V. 2005. Genetic diversity among coconut (Cocos nucifera $\mathrm{L}$.) genotypes using isozymes. Asian J Plant Sci 4 (6): 678-683.

Global Invasive Species Database (GISD). 2015. Species profile Anredera cordifolia. . http://www.iucngisd.org/gisd/species.php?sc=776

Ivy NA, Biswas MS, Rasul G, Hossain T, Mian MAK. 2010. Variations of genotypes of radish at molecular level using isozyme analysis for the identification of self-incompatible lines. Glob J Biotechnol Biochem 5 (1): $19-26$.

Johnson M, Nanthini AUR, Malar TRJJ.2010. Isozyme variation and genetic relationships among three Plumbago species. J Ecobiotechnol 2/5: 54-59.

Kartika GRA, Andayani S, Soelistyowati. 2016. Potential of binahong (Anredera cordifolia) leaf extract as an inhibitor of Vibrio harveyi bacteria. J Mar Aquat Sci 2: 49-53. [Indonesian]

Kinupp VF, Amaro FS, Barros IBI. 2004. Anredera cordifolia (Basellaceae), uma hortaliça potencial em desuso no Brasil. Hortic Bras 22: 346

Klaas M. 1998. Applications and impact of molecular markers onevolutionary and diversity studies in Allium. Plant Breed 117: 297 308.

Kumalasari E, Sulistyani N. 2011. Antifungal activity of ethanol extract of binahong stem (Anredera cordifolia (Ten.) Steen) against Candida albicans and phytochemical screening. J Ilmiah Kefarmasian 1: 5162. [Indonesian]

Kumar OA, Tata SS, Kumar KP. 2013. Analysis of several popular cultivars of Madagascar Periwinkle (Catharanthus roseus (L.) G. Don.) using biochemical markers. Not Sci Biol 5 (4): 458-461.

Lange O, Schifino-Wittmann MT. 2000. Isozyme variation in wild and cultivated species of the genus Trifolium L. (Leguminosae). Ann Bot 86: 339-345.

Lombardi M, Materne M, Cogan NOI, Rodda M, Daetwyler HD, SlaterAT, Forster JW, Kaur S. 2014. Assessment of genetic variation within a global collection of lentil (Lens culinaris Medik.) cultivars and landraces using SNP markers. BMC Genet 15: 150. DOI: 10.1186/s12863-014-0150-3.

Mao-Te C, Yin-Shiou L, Wen-Chi H. 2007. Ancordin, the major rhizome protein of Madeira-vine, with trypsin inhibitory and stimulatory activities in nitric oxide productions. Peptide 28 (6): 1311-1316.

Martinevski CS, Oliveira VR, Rios AO, Flores SH, Venzke JG. 2013. Utilização de Bertalha (Anredera cordifolia (Ten.) Steenis) e OraPro-Nobis (Pereskia aculeata Mill.) na elaboração de pães. Braz J Food Nutr 24: 255-370.

Mbouobda HD, Boudjeko T, Djoegoue PF, Tsafack TJJ, Omokolo DN 2007. Morphological characterization and agronomic evaluation of Cocoyam (Xanthosoma sagittifolium (L.) Schott) germplasm in Cameroon. J Biol Sci 7 (1): 27-33.

Miladiyah I, Prabowo BR. 2012. Ethanolic extract of Anredera cordifolia (Ten.) Steenis leaves improved wound healing in Guinea pigs. Univ Med 31: 4-11. [Indonesian]

Murni AS, Sakinah AMM, Andayani BMR, Awalludin R. 2011. Determination of saponin compound from Anredera cordifolia (Ten.) Steenis plant (Binahong) to potential treatment for several diseases. J Agric Sci 3: 224-232.

Nongdam P, Nirmala C. 2007. Genetic variability in four species of Cymbidium based on isozyme markers. Physiol Mol Biol Plants 13 (1): 65-68.

Orbayinah S, Kartyanto A. 2008. Efficacy of binahong (Anredera cordifolia (Tenore) Steenis) leaf to alkaline phosphatase level. Mutiara Med 8 (2): 89-95. [Indonesian]

Padmini SMPC, Pushpakumara DKNG, Samarasekera R. 2013. Morphological characterization of soursop (Annona muricata L.) germplasm in Sri Lanka. Trop Agricult Res 24 (4): 362-374.

Panyaphua K, On TV, Sirisaard P, Srisangac P, Chansa Kaowa S, Nathakarnkitkul S. 2011. Medicinal plants of the mien (yao) in Northern Thailand and their potential value in the primary healthcare of postpartum women. J Ethnopharmacol 135: 226-237.
PIER [Pacific Islands Ecosystems at Risk]. 2000. Invasive Plant Species: Anredera cordifolia. http://www.hear.org/pier/ancor.htm

Pitaloka DAE, Sukandar EY. 2018. Synergistic study on n-Hexane Extract of Anredera cordifolia (Ten.) Steenis leaves combined with antituberculosis drugs against drug-sensitive and drug-resistant of Mycobacterium tuberculosis. J App Pharm Sci 8 (05): 134-138.

Pitoyo A. Prameta AA, Marsusi, Suratman, Suranto.2018. Morphological, anatomical and isozyme variability among taro (Colocasia esculenta) accessions from southeastern part of Central Java, Indonesia. Biodiversitas 19 (5): 1811-1819.

Rakshit A, Sarvari P, Rakshit S, Dadlani M. 2011. Characterization of hybrids and parental lines of maize using isozyme markers for DUS testing. Seed Res 39: 156-160.

Rohlf SJ. 1998. NTSYS-pc Numerical Taxonomy and Multivariate Analysis System. Exeter Software, New York.

Roy S, Islam MA, Sarker A, Malek MA, Rafii MY, Ismail MR.2013.Determination of genetic diversity in lentil germplasm based on quantitative traits. Aust J Crop Sci 7 (1):14-21.

Sabaghnia N, Janmohammadi M, Bashiri A, Asghari-Shirghanr R. 2014. Genetic variation of several bread wheat (Triticum aestivum L.) genotypes based on some morphological traits. Ann Univ Mariae Curie-Sklodowska Lublin-Polonia 69 (1): 44-54.

Said WM, Ehsan NOM. 2010. Morphological and molecular evidence among four heteroforms of Avicennia marina (Forssk) Vierh. J Am Sci 6 (11): 843-856

Setyawan AD, Wiryanto, Suranto, Bermawie N. 2014. Short communication: variation in isozymic pattern of germplasm from three ginger (Zingiber officinale) varieties. Nusantara Biosci 6 (1): 86-93.

Smila KH, Johnson M, Rajasekarapandian M. 2007. Studies on varietal difference, tissue specificity and developmental variation of esterase and peroxidase isozymes in pearl millet (Pennisetum glaucum (L.) R.Br.). Indian J Biotechnol 6: 91-99.

Souza LF, de Barros IBI, Mancini E, de Martino L, Scandolera E, de Feo V. 2014. Chemical composition and biological activities of the essential oil from Anredera cordifolia grown in Brazil. Nat Prod Commun 9 (7): 1003-1006.

Starr F, Starr K, Loope L. 2003 Anredera cordifolia (Madeira vine, Basellaceae). United States Geological Survey, Biological Resources Division, Haleakala Field Station, Hawaii.

Sukandar EY, Qowiyyah A, Larasati L. 2011. Effect of methanol extract heart leaf madeira vine (Anredera cordifolia (Ten.) Steenis) leaves on blood sugar in diabetes mellitus model mice. J Med Plant 1 (4): 1-10. [Indonesian]

Sukandar EY, Sigit JI, Adiwibowo LF. 2013. Study of kidney repair mechanisms of corn silk (Zea mays L.) hair-binahong (Anredera cordifolia (Ten.) Steenis) leaves combination in rat model of kidney failure. Int J Pharmacol 9: 12-23.

Sumartiningsih S. 2011. The effect of binahong to hematoma. Waset 78: 743-745.

Suranto. 2001. Studies on Ranunculus population: isozymic pattern. Biodiversitas 2 (1): 85-91.

Suratman, Pitoyo A, Kurniasari S, Suranto. 2016. Morphological, anatomical and isozyme variation among giant taro (Alocasia macrorrhizos) accessions from Central Java, Indonesia. Biodiversitas 17 (2): 422-429.

Suratman, Pitoyo A, Mulyani S, Suranto. 2015. Assessment of genetic diversity among soursop (Annona muricata) populations from Java, Indonesia using RAPD markers. Biodiversitas 16 (2): 247-253.

Suratman, Pitoyo A, Mulyani S. 2013. Analysis of genetic variability in soursop (Annona muricata L.) populations from Central Java and East Java based on Random Amplified Polymorphic DNA (RAPD) marker. J Biol Res 19: 15-19.

Tang XQ, Yan HH, Wang ZY, Li W, Wei YM, Ren CZ, Zha G, Peng YY. 2014. Evaluation of diversity and the relationship of Avena species based on agronomic characters. Int J Agric Biol 16 (1): 14-22.

The Plant List. 2013. Version 1.1. 'Basellaceae'. www.theplantlist.org/browse/A/Basellaceae.

Tikader A, Kamble C. 2008. Genetic diversity of Morus species of indigenous and exotic accessions evaluated by important agronomical traits. Philippine J Sci 137 (1): 29-38.

Tiwari C, Bakshi M. 2015. Genetic diversity and phylogenetic relationship among accessions of Drepanostachyum falcatum (Nees) Keng f. from the Garhwal Himalayas. Proceeding 10th World Bamboo Congress, Seoul, South Korea. 
Typical Gardener. 2014. Anredera cordifolia aka madeira vine or mignonette vine. https://typicalgardener.wordpress.com/2014/06/27/ anredera-cordifolia-aka-madeira-vine-or-mignonette-vine

Vivian-Smith G, Lawson BE, Turnbull I, Downey PO. 2007. The biology of Australian weeds. 46. Anredera cordifolia (Ten.) Steenis. Plant Prot Q 22: 2-10.

Wang L, Bang CY, Choung SY. 2011.Anti-obesity and hypolipidemic effects of Boussingaultia gracilis Miers var. pseudobaselloides Bailey in obese rats. J Med Food 14 (1-2): 17-25.
Webb HJ, Harrington KC. 2005. Control strategies for madeira vine (Anredera cordifolia). N Z Plant Prot 58: 169-173.

Yen GC, Chen HY, Peng HH. 2001. Evaluation of the cytotoxicity, mutagenicity and antimutagenicity of emerging edible plants. Food Chem Toxicol 39: 1045-1053.

Zeid AHS, Soliman FM, Sleem AA, Mitry MNR. 2007. Phytochemical and bio-activity investigations of the aerial parts of Anredera cordifolia (Ten.) Steenis. Bull Nat Res Cent (Egypt) 32: 1-33. 